\title{
Pedagógushallgatók fogyatékKal ÉLŐK EGYÜTTNEVELÉSÉRŐL ALKOTOTT VÉLEMÉNYEI
}

\author{
KOVÁCS EDINA ${ }^{a, *}-$ BIHARI ZSANETT'b \\ ${ }^{a}$ Debreceni Egyetem, CHERD Hungary \\ ${ }^{\mathrm{b}}$ Debreceni Egyetem
}

Jelen tanulmány célja, hogy feltárja a Debreceni Egyetem pedagógushallgatóinak inkluzív neveléssel kapcsolatos véleményét, valamint a fogyatékossággal élő személyek iránti attitűdjét. A vizsgálatban 101, osztatlan tanárképzésbe, illetve óvodapedagógus képzésbe járó hallgató vett részt. Az adatfelvétel papíralapú kérdőívvel, valószínűségi mintavétellel történt 2018 októberében és novemberében. A tanár szakos, illetve az óvodapedagógus képzésben részt vevő hallgatók attitüdje enyhén negatív, szignifikáns eltérést nem találtunk a két csoport között. Elméleti, illetve gyakorlati ismeretek terén a két hallgatói csoport eltérő mértékben érzi magát felkészültnek, mindez azonban nem eredményez szignifikáns eltérést az együttnevelésre való nyitottságban, illetve egy részük esetében az ettől való elzárkózásban.

Kulcsszavak: pedagógusképzés, sajátos nevelési igényü gyermek, inkluzív nevelés

Aim of this study to examine the attitude of students in teacher training at the University of Debrecen to disabled people and their opinion on inclusive education. We asked 101 students who attend undivided teacher training and kindergarten teacher training. They filled a questionnaire, selected by probability sampling, in October and November 2018. The attitude of both groups slightly negative, there were no significant differences between them. In terms of theoretical and practical knowledge, the two groups of students feel differently prepared, but this does not result in a significant difference in openness towards inclusive education.

Keywords: teacher training, children with special needs, inclusive education

\footnotetext{
* Levelező szerző: Kovács Edina, Debreceni Egyetem, 4032 Debrecen, Egyetem tér 1.

E-mail: kovacs.edina.12@gmail.com
} 


\section{Bevezetés}

A sérült emberek hatékony fejlesztése emberi jogi, etikai kérdés, azonban társadalmi és finanszírozási következményekkel is jár. Az elmúlt két évtized során egész Európában egyre fontosabbá vált a sérült egyének minél korábbi felkészítése a társadalmi integrációra, ezáltal kiemelt szerepet kapott az óvodák, iskolák nevelési, fejlesztési gyakorlata. A korábbi szegregált nevelés kritikája az 1990-es években kezdett felerősödni: kiemelték a rendszer diszkriminatív voltát, és azt is, hogy az egyes intézmények és az otthon közötti távolság a sérült gyermekeket a családtól való elszakadásra kényszerítette. Ráadásul a hasonló fogyatékosságtípussal rendelkező gyermekek esetében sem egyértelmü, hogy homogén csoportokat lehet létrehozni, hiszen köztük is nagy egyéni eltérések lehetnek (Némethné 2009; Réthyné 2002).

$\mathrm{A} z$ együttnevelés mellett számos érv szól, például csökken a sérült gyermekek izolációja, de kedvező lehet azoknak is, akik épek ugyan, de társadalmi helyzetük miatt marginalizálódtak, és emiatt igényelnek több figyelmet. Fontos tényező a fogyatékosság típusa is. Az integrációt vizsgáló kutatások egy része kitér ennek megválaszolására, eredményeik többnyire egybehangzóak. Ezek szerint az érzékszervi sérüléssel élőket sokkal inkább találják integrálhatónak, mint például a mozgáskorlátozottsággal vagy értelmi akadályozottsággal élőket. Elképzelhető, hogy van, aki szegregált nevelést igényel, ennek azonban alternatívaként kellene megjelennie, hogy az egyéni szükségletek szerint lehessen választani (Fischer 2009; Foreman 2001; Horváthné 2006; Loreman 2002; Pongrácz 2005; Szabó 2016; Szegő 2008).

$\mathrm{A} z$ együttnevelés akkor lehet hatékony, ha ahhoz a megfelelő feltételek is rendelkezésre állnak, ellenkező esetben csupán az akadályozott gyermekek és nem akadályozott társaik együtt élő halmaza jön létre. Az együttnevelés objektív feltételei közé sorolják a szakemberek a megfelelő jogszabályi hátteret és a tárgyi feltételek meglétét. A pedagógus felkészültsége, attitűdje is legtöbbször a tárgyi feltételek között jelenik meg, bár illeszthető a szubjektív feltételek közé is, különösen, ha a pedagógus és a gyógypedagógus kapcsolatát, együttmüködési készségét vizsgáljuk. Az osztálytársak viszonyulása fogyatékossággal élő társaikhoz, valamint a család támogató hozzáállása pedig egyértelműen szubjektív feltétel (Alghazo-Dodeen-Algaryouti 2003; Csányi 1993).

\section{A kutatás hazai és nemzetközi előzményei}

A pedagógusok kulcsszerepét az együttnevelésben szinte minden tanulmány hangsúlyozza. Alapvető, hogy nyitottak legyenek az integrációra, reflektíven viszonyuljanak saját nevelői tevékenységükhöz (Németbné 2009; Réti-Csányi 1998; Szegő 2008). Tisztában kell lenniük az egyes részképességzavarokkal, fogyatékossági típusokkal, továbbá azzal, hogy milyen bánásmódot igényel az ezek valamelyikével rendelkező gyermek (Baloghné 2013; Csányi 2001). Az is fontos, hogy megfelelő nevelési helyzeteket tudjanak kialakítani. Lynas (1995) hallássérült és halló gyermekek együttnevelése kapcsán kiemeli, hogy a pedagógusok aktívan tudják fejleszteni a szociális integrációt, ha olyan helyzeteket hoznak létre, amelyekben a halló és a nem halló gyermekek kooperációjára van szükség. Lényeges, hogy ezekben a helyzetekben a hallássérült gyermekek egyenlö félként vehessenek részt, hogy a hallókhoz viszonyított státusukat emelni tudják. 
Mindezek következtében számos kutatás vizsgálta a pedagógusok felkészültségét, attitűdjét, az együttneveléshez történő hozzáállásuk hátterében rejlő tényezőket. E kutatások általában arra világítottak rá, hogy a pedagógusok gyakran tájékozatlanok az együttneveléssel, valamint a fogyatékossági típusokkal kapcsolatban, nincs megfelelő eszköztáruk a korábban nem tapasztalt problémák és helyzetek kezelésére. Mivel nincs megfelelő tudásuk és támogató hátterük, a kihívásokat kudarcként élik meg. Emiatt az együttnevelést sokszor negatívabbnak ítélik meg, mint ami reális lenne, ritkán emelnek ki pozitív jellemzőt vagy előnyt (Perlusz-Torda 2010; Réti-Csányi 1998; Szabó 2016).

Soproni óvodapedagógus hallgatókat vizsgálva az derült ki, hogy a megkérdezettek mindössze 23 százaléka gondolja, hogy el tudná kezdeni az együttnevelést, mivel teljesen vagy többé-kevésbé felkészültnek érzi magát. Egytizedük egyáltalán nem merné vállalni a feladatot, a fennmaradó hányad pedig részben felkészült, de segítséget igényelne. A képzés során szinte minden hallgató tanult valamilyen keretben a speciális nevelési igényü gyermekekről (mindössze egy százalék válaszolt nemmel erre a kérdésre), de többségük nem önálló tárgy keretében, hanem valamilyen más kurzusba beépítve. A megkérdezettek közel fele ugyanakkor nyitott lenne az együttnevelésre, a többiek pedig elsősorban saját tudásuk hiányosságai miatt látják akadályozónak az integrált vagy inkluzív nevelést (Baloghné 2013).

A pályán levő pedagógusok attitüdjét vizsgáló kutatások arra hívják fel a figyelmet, hogy a speciális nevelési igényü gyermekek iránti elöítéletességet határozottan csökkenti, ha a pedagógus rendelkezik saját tapasztalattal e téren, és ehhez megfelelő tudás és/ vagy intézményi háttér társul. A speciális ismeretek azonban - mintavételtől függően - a megkérdezettek fele-kétharmada esetén hiányoznak. Az is lényeges tényező, hogy képzésétől, iskolai tapasztalatától függetlenül - ismer-e a megkérdezett pedagógus saját környezetében fogyatékossággal élö személyt: ha igen, akkor az csökkenti az elöítéletességet. A különböző akadályozottsággal rendelkező gyermekeket a pedagógusok eltérő mértékben ítélik integrálhatónak: Horváthné (2006) eredményei szerint a szellemileg elmaradott tanulók elfogadottsága a legkisebb, míg Szabó (2016) arra az eredményre jutott, hogy az autista és egyéb pszichés zavarral rendelkező gyerekek a leginkább elutasítottak (Horváthné 2006; Némethné 2009; Szabó 2016).

Azok a kutatások, amelyek a pedagógushallgatók attitűdjét vizsgálták, jelzik, hogy a képzés során reflektálni kellene a hallgatók fogyatékossággal élőkkel kapcsolatos képzeteire, és aggályaikra is, mivel attitüdjük enyhén negatív. A nemzetközi vizsgálatok azt is kimutatták, hogy az egyes országok pedagógushallgatói között komoly eltérések lehetnek, például az adott társadalom elfogadó vagy elutasító hozzáállása, vagy a jogszabályi háttér kidolgozottsága mentén, összességében azonban az eredmények enyhe negatív attitüdöt jeleznek. Egy kutatás, amely jordániai és egyesült arab emírségekbeli tanár szakos hallgatókat vizsgált, rákérdezett arra is, hogy a hallgató saját környezetében találkozik-e fogyatékossággal élő személlyel. A kutatás eredménye szerint a találkozási gyakoriság nem mutatott ki szignifikáns eltérést az enyhe negatív attitüdben (Alghazo-DodeenAlgaryouti 2003; Baloghné 2013; Sharma et al. 2006).

\section{A kutatás módszere}

Jelen kutatásunk során a Debreceni Egyetem pedagógushallgatóit kérdeztük azzal a céllal, hogy az együttnevelésről alkotott véleményüket, az erre való felkészültségüket és a 
fogyatékossággal élők iránti attitűdjüket feltérképezzük. Összesen 101, osztatlan tanárképzésben, illetve óvodapedagógus képzésben részt vevő hallgató véleményét vizsgáltuk. Két okból döntöttünk az óvodapedagógus, illetve a tanár szakos hallgatók összehasonlítása mellett: az egyik, hogy a 2017/2018-as tanév során a Debreceni Egyetem harmadéves óvodapedagógus hallgatói még csak választható kurzus keretében tanultak gyógypedagógiai ismereteket, míg a tanár szakosok számára a speciális nevelési igényű diákokkal foglalkozó tantárgy kötelező. Emiatt arra voltunk kíváncsiak, hogy a mindenki által megszerzett ismeretek előnyként jelennek-e meg a tanár szakosoknál, felkészültebbnek érzik-e magukat az együttnevelésre, mint az óvodapedagógus hallgatók. Továbbá arra is választ kerestünk, hogy az óvodapedagógus-képzés esetén a választható ismeretek nagyobb rugalmassággal, elfogadóbb attitűddel járnak-e az óvodapedagógusok számára, mint a kötelező kurzusként tanult ismeretek a tanár szakosok számára.

A mintába harmadéves óvodapedagógus hallgatók és negyedéves, osztatlan tanárképzésben részt vevő hallgatók kerültek, valószínüségi mintavétellel. Az adatfelvétel 2018 októberében és novemberében történt. A hallgatók aránya a mintán belül: 61,9 százalékuk óvodapedagógus, 38,1 százalékuk tanárképzésben vesz részt. A megkérdezett hallgatók átlagéletkora 22 év (szórás 1,28).

Kérdőívünk négy nagyobb kérdésblokkot tartalmazott: az első a jelenlegi és a korábbi végzettségekre, a második a sajátos nevelési igényű gyermekekkel kapcsolatos ismeretekre és pedagógusi munkára, a harmadik az egyes fogyatékosságtípusokkal kapcsolatos vélekedésekre, míg a negyedik a demográfiai adatokra kérdezett rá. A kérdőív része továbbá az Attitudes Towards Disabled Persons (ATDP) - vagyis a fogyatékkal élők iránti attitűdöket mérő - skála, amit Yuker és munkatársai dolgoztak ki (Yuker-BlockYounng 1970). Az eredetileg angol nyelvű skálát magyarra fordítottuk, fordításunkat két független személy ellenőrizte, az általuk ajánlott módosításokkal korrigáltuk a mérőeszközt. Az ATDP 6 fokú Likert-skálát használ, amelyen az 1-es érték jelenti azt, hogy a megkérdezett egyáltalán nem ért egyet az adott állítással, a 6-os pedig azt, hogy teljes mértékben egyetért.

\section{Kutatási eredmények}

A teljes mintában a férfiak aránya mindössze 15,3 százalék, mindegyikük a tanár szakos megkérdezettek köréből került ki. A szülők legmagasabb iskolai végzettsége jellemzően középfokú, az apák háromnegyede és az anyák kétharmada rendelkezik ilyen végzettséggel. A megkérdezettek lakóhelyének településtípusa egyenletesen oszlik meg a falu, a kisebb és a nagyobb város, valamint a megyeszékhely között. A demográfiai változók alapján a fogyatékossággal élőkhöz, illetve az együttneveléshez való viszonyulásban - az egyes kategóriák átlagértékeinek összehasonlítását lehetővé tévő ANOVA-próba alapján - nem találtunk szignifikáns eltéréseket.

A kérdezettek mindegyike legalább átlagosnak értékeli tanulmányi eredményét: 8,2 százalékuk átlagosnak, a többiek pedig jónak vagy kiválónak. Felsőfokú képzésben korábban mindössze 10,3 százalékuk vett részt, ezen belül pedagógiához kapcsolódó területen mindössze 5,2 százalék - ők az elméleti ismeretek terén felkészültebbnek érzik magukat a többieknél, azonban a gyakorlati ismeretek és az együttnevelésre való felkészültség tekintetében már nem tapasztalható eltérés -, így a korábbi képzések nem befolyásolják erőteljesen az eredményeket. Diplomaszerzést követően többségük $(77,8$ 
százalék) pedagógusként szeretne dolgozni, a bizonytalanok aránya szignifikánsan magasabb a leendő tanárok körében, mint az óvodapedagógusnak tanulók esetében (Khínégyzet próba: $p=0,025)$.

A hallgatók jelenlegi képzésével kapcsolatban az elméleti és a gyakorlati ismereteikre is rákérdeztünk, továbbá arra is, hogy hospitálásuk során találkoztak-e együttneveléssel, hiszen ez is jelentősen befolyásolhatja, hogy mennyire érzik felkészültnek magukat. A válaszokat az 1. táblázatban mutatjuk be.

1. táblázat: A hallgatók képzés során szerzett ismereteinek alakulása (\%)

\begin{tabular}{|c|c|c|c|c|c|}
\hline & $N$ & Igen & Inkább igen & Inkább nem & Nem \\
\hline \multicolumn{6}{|c|}{ A képzésem során kaptam elméleti ismereteket a sajátos nevelési igényü gyermekekröl. } \\
\hline Óvodapedagógus & 61 & 48,3 & 38,3 & 10,0 & 3,4 \\
\hline Tanárképzésben részt vevő & 40 & 18,9 & 35,1 & 37,8 & 8,2 \\
\hline \multicolumn{6}{|c|}{ A képzésem során szereztem gyakorlati ismereteket a sajátos nevelési igényü gyermekekröl } \\
\hline Óvodapedagógus & 61 & 3,3 & 28,3 & 36,7 & 31,7 \\
\hline Tanárképzésben részt vevő & 40 & 2,8 & 5,6 & 13,8 & 77,8 \\
\hline \multicolumn{6}{|c|}{ A bospitálásom/gyakorlatom során találkoztam sajátos nevelési igényü gyermekekkel } \\
\hline Óvodapedagógus & 59 & 40,7 & 18,6 & 23,8 & 16,9 \\
\hline Tanárképzésben részt vevő & 39 & 0,0 & 5,6 & 16,6 & 77,8 \\
\hline
\end{tabular}

Megjegyzés: A Khí-négyzet próba szignifikanciaértéke az első kérdés esetében: $p=0,002$, a második és a harmadik esetében: $p=0,000$.

Az adatokból látszik, hogy a tanár szakos hallgatók kevesebb mint fele (46 százaléka) véli úgy, hogy nem kapott elegendő elméleti ismeretet a képzése során, noha a speciális nevelési igényű diákokkal foglalkozó kurzusuk a harmadik évfolyamon teljesítendő. Természetesen előfordulhat, hogy valaki „csúszásban” van, de ezt a magas arányt ez semmiképp sem magyarázza. Az óvodapedagógus hallgatók körében az arány alig haladja meg a tíz százalékot, és a gyakorlati ismeretek tekintetében is szignifikánsan képzettebbnek vélik magukat, mint a tanár szakosok. Azonban arra a kérdésre, hogy mennyire érzik magukat felkészültnek az együttnevelésre, a hallgatói csoportok válaszai között nem volt szignifikáns eltérés. A valamennyire felkészült óvodapedagógus hallgatók aránya szinte azonos a Baloghné (2013) által vizsgált soproni hallgatók körében kapott eredménnyel, míg a tanár szakosok esetében valamivel kedvezőtlenebb a helyzet. Az óvodapedagógusok negyede, a tanár szakosok egytizede érzi magát nagyobbrészt felkészültnek, a többiek nem, vagy csupán kevéssé; azaz, bár valamilyen mértékben megmutatkozik a több ismeret hatása az óvodapedagógus hallgatóknál, ez nem eredményez szignifikánsan kedvezőbb felkészültségérzetet.

A kérdezett hallgatók 57,3 százaléka egyetért azzal az állítással, hogy aránytalan terhet ró egy pedagógusra, ha csoportjában vagy osztályában speciális nevelési igényü gyermekek vannak. Valamivel több mint egyharmaduk nem szívesen dolgozna integráltan nevelő osztályban vagy óvodai csoportban. Ebben szintén nem mutatkozott szignifikáns eltérés az óvodapedagógus és a tanár szakos hallgatók között. Az elfogadást - vagy elutasítást - egy személyesebb kérdéssel is igyekeztünk feltárni, ami így szólt: „Saját (leendő) 
gyermekét járatná-e olyan csoportba és/vagy osztályba, amelyben sérült gyermek is van?" Teljesen elutasító választ a kérdezett hallgatók egytizede adott, mind a tanár szakos, mind az óvodapedagógus hallgatók körében. Igennel 42 százalékuk válaszolt, a tanár szakosok köréből valamivel többen, de az eltérés nem szignifikáns. A többiek - nagyjából a kérdezettek fele - a sérülés fokától vagy típusától teszik függővé, hogy saját gyermeküket mennyire szívesen adnák ilyen közösségbe.

A hallgatókat arról is megkérdeztük, hogy mennyire tartják integrálhatónak az egyes sérüléstípusokkal rendelkező gyermekeket. A tanulmányunk elméleti részében bemutatott kutatások eredményével összhangban az általunk vizsgált hallgatók is az autista, illetve az egyéb pszichés fejlődési rendellenességgel bíró gyermekekről gondolják, hogy nem integrálhatóak, és idesorolják a halmozottan sérülteket is. A tanár szakosok esetében a nehezebben integrálható kategóriába kerültek a hallássérültek is, őket az óvodapedagógus hallgatók inkább vélik integrálhatónak, az eltérés a két csoport megítélése között szignifikáns. A két hallgatói csoport között szignifikáns véleménykülönbség emellett a mozgáskorlátozottakat illetően adódik: a tanár szakosok őket tartják a legkönynyebben integrálhatónak, míg az óvodapedagógus hallgatók a látássérült és a hallássérült gyerekek közé sorolták be őket (2. táblázat). A többi sérüléstípus esetén, bár érzékelhetőek eltérések a két hallgatói csoport között, a véleménykülönbségek nem szignifikánsak.

2. táblázat: Az egyes sérüléstípusba sorolható gyermekek integrálhatósága a hallgatók szerint $(N=101)$

\begin{tabular}{llrrr}
\hline \multirow{2}{*}{ Halmozottan sérült } & & Nem & Talán & Igen \\
\hline \multirow{2}{*}{ Autista } & Óvodapedagógus hallgatók & 50,0 & 48,3 & 1,7 \\
& Tanár szakos hallgatók & 54,3 & 44,6 & 1,1 \\
\hline \multirow{2}{*}{ Egyéb pszichés fejlődési zavarral } & Óvodapedagógus hallgatók & 38,3 & 48,4 & 13,3 \\
rendelkező & Tanár szakos hallgatók & 37,1 & 51,4 & 11,5 \\
\hline \multirow{2}{*}{ Értelmileg akadályozott } & Óvodapedagógus hallgatók & 28,3 & 60,0 & 11,7 \\
& Tanár szakos hallgatók & 37,5 & 43,8 & 18,7 \\
\hline \multirow{2}{*}{ Látássérült } & Óvodapedagógus hallgatók & 27,1 & 59,3 & 13,6 \\
& Tanár szakos hallgatók & 52,9 & 44,2 & 2,9 \\
\hline \multirow{2}{*}{ Mozgáskorlátozott ${ }^{*}$} & Óvodapedagógus hallgatók & 18,6 & 37,3 & 44,1 \\
& Tanár szakos hallgatók & 20,0 & 48,6 & 31,4 \\
\hline \multirow{2}{*}{ Tanulásban akadályozott } & Óvodapedagógus hallgatók & 11,7 & 46,6 & 41,7 \\
& Tanár szakos hallgatók & 0,0 & 16,7 & 83,3 \\
\hline \multirow{2}{*}{ Beszédsérült } & Óvodapedagógus hallgatók & 10,5 & 38,6 & 50,9 \\
& Tanár szakos hallgatók & 22,2 & 44,4 & 33,4 \\
\hline \multirow{2}{*}{ Hallássérült* } & Óvodapedagógus hallgatók & 8,8 & 42,1 & 49,1 \\
& Tanár szakos hallgatók & 8,8 & 61,8 & 29,4 \\
\hline & Óvodapedagógus hallgatók & 6,7 & 53,3 & 40,0 \\
& Tanár szakos hallgatók & 25,7 & 65,7 & 8,6 \\
\hline
\end{tabular}

Megjegyzés: *Szignifkáns különbség Khí-négyzet próba alapján $(p<0,05)$ 
A hallgatók attitűdjét a fogyatékossággal élő személyek iránt az Attitudes Towards Disabled Persons (ATDP) skálával mértük. A skála 20 állítást tartalmaz, a válaszokat hatfokú Likert-skálán lehet megjelölni, amelyen az 1-es érték jelenti azt, hogy a megkérdezett egyáltalán nem ért egyet az adott állítással, a 6-os pedig azt, hogy teljes mértékben egyetért. Így a minimálisan elérhető érték 20 pont, ez a leginkább negatív attitüd, a maximális érték 120 pont, ez a leginkább pozitív attitűd. Az általunk megkérdezett pedagógushallgatók attitűdje enyhén negatív, az óvodapedagógusok és a tanár szakosok eredménye között nem mutatható ki szignifikáns eltérés (3. táblázat).

3. táblázat: A hallgatók attitűdje az ATDP skálán

\begin{tabular}{lcc}
\hline & $N$ & Az ATDP skála átlaga \\
\hline Óvodapedagógus hallgatók & 61 & 66,8 \\
Tanár szakos hallgatók & 40 & 66,4 \\
\hline
\end{tabular}

A hallgatók attitüdjében sem a demográfiai változók alapján nem volt eltérés, sem aszerint, hogy valaki a képzése során mennyi elméleti vagy gyakorlati ismeretre tett szert. Az egyetlen szignifikáns eltérés annak mentén mutatkozott, hogy valakinek saját közvetlen környezetében él-e sérült személy (4. táblázat). Az elemszám ugyan nagyon kicsi, mivel

4. táblázat: A hallgatók attitűdje, fogyatékossággal élő személyekkel való kapcsolat szerint

\begin{tabular}{lc}
\hline $\begin{array}{l}\text { Többé vagy kevésbé rendszeres személyes kapcsolatban áll-e } \\
\text { fogyatékossággal élő személlyel? }\end{array}$ & Az ATDP átlaga \\
\hline Igen, saját szúkebb családomban. & 74,2 \\
Igen, a tágabb családi körben. & 65,5 \\
Igen, rokonságomon belül. & 56,0 \\
Igen, az utcámban (lakókörnyezetemben). & 63,0 \\
Igen, közeli barátaim körében. & 47,0 \\
Igen, tágabb ismeretségi körömben. & 67,3 \\
Nem, nem élnek sérült emberek a környezetemben. & 67,3 \\
\hline
\end{tabular}

Megjegyzés: Anova-próba szignifikanciaértéke: 0,044 ( $N=101)$

a kérdezettek fele azt válaszolta, hogy környezetében egyáltalán nem él sérült személy, mégis úgy véljük, hogy érdemes ezt az eredményt figyelembe venni, és későbbi kutatások során többet megtudni a hátterében álló okokról. A kis elemszám miatt nem bontottuk óvodapedagógus és tanár szakos hallgatókra a mintát. Ezt azért tartottuk indokoltnak, mert ennek alapján nem mutatkozott szignifikáns eltérés az attitüdben. Az eredményt már csak azért is érdemes, a felsorolt korlátokat szem előtt tartva, figyelembe venni, mert igen hasonló az Alghazo és munkatársai által kapott eredményekhez (Alghazo-DodeenAlgaryouti 2003). Abban a kutatásban a találkozás gyakoriságára kérdeztek rá, és eszerint nem tudtak szignifikáns eltérést kimutatni az attitüdben. Ugyanakkor a leginkább pozitívan azok viszonyultak a fogyatékossággal élőkhöz, akik havi egy alkalommal érint- 
keztek ilyen személlyel, a leginkább negatív attitűdje pedig azoknak volt, akik hetente egyszer találkoztak fogyatékossággal élőkkel. Ez, valamint saját eredményünk arra hívja fel a figyelmet, hogy a kedvezőbb attitűdhöz nem elég csupán ismerni egy fogyatékossággal élő személyt, hanem vélhetően a kapcsolat minősége is fontos tényező.

A megkérdezett hallgatók legkevésbé azzal az állítással értettek egyet, hogy „Nincs szükség speciális iskolákra a fogyatékossággal élő gyermekek számára”, azaz többségükben a szegregált nevelés mellett voksoltak. Legnagyobb arányban pedig "A testi fogyatékossággal élö emberek ugyanolyan intelligensek, mint az épek (fogyaték nélkül élök)" és „A fogyatékossággal élö emberek ugyanolyan boldogok, mint az épek” álltásokkal értettek egyet. Az attitűdskála kijelentéseit az egyetértés alapján egytől húszig sorba rendezve alig mutatkozik eltérés az óvodapedagógus hallgatók és a tanár szakos hallgatók besorolásai között. A legnagyobb eltérés két kijelentés kapcsán látszikः „A fogyatékossággal élö emberek többnyire hajlamosak egymás között lenni” - az óvodapedagógus hallgatók ezzel inkább egyetértettek ( 5 . helyre sorolták, szemben a tanár szakosok 8 . helyével), míg "A fogyatékossággal élö emberek többsége úgy érzi, hogy nem olyan értékes, mint más emberek" kijelentést a tanár szakosok fogadták nagyobb egyetértéssel: 6 . helyre került az ő rangsorolásuk szerint, szemben az óvodapedagógus hallgatók 11. helyével.

\section{Összegzés}

Kutatásunk során a Debreceni Egyetem pedagógushallgatóinak együttneveléshez való viszonyát, felkészültségét, továbbá a fogyatékossággal élők iránti attitűdjét vizsgáltuk. Eredményeink tehát erre az egy felsőoktatási intézményre érvényesek, ugyanakkor meglehetősen egybevágnak a korábbi hazai és nemzetközi kutatások által feltárt eredményekkel.

Speciális felkészítés alatt olyan érzékenyítő program értendő, amely több mint csupán elméleti ismeretek átadása. Eredményeink szerint ugyanis ez önmagában kevés: a tanár szakos hallgatók csaknem fele érzi úgy, hogy nem kapott a sajátos nevelési igényü diákokról elméleti ismereteket, noha az erről szóló kurzus része a képzésüknek, gyakorlati ismeretekhez pedig még tíz százalékuk sem jutott. Az óvodapedagógus hallgatók mind az elméleti, mind a gyakorlati ismeretek terén valamivel jobb helyzetben érzik magukat, ez azonban nem jelenik meg az együttnevelésre való felkészültség érzésében. $\mathrm{A} z$ természetesen érthető, hogy a hallgatói pozícióban még nem tartják magukat teljes mértékben felkészültnek a megkérdezettek; ezt a tapasztalatok hiánya önmagában is indokolná. Elgondolkodtató azonban, hogy nagyobbrészt felkészültnek is mindössze az óvodapedagógusok negyede, a tanár szakosok egytizede érzi magát. Nem igazolódott tehát az a feltételezésünk, hogy a kötelezően megszerzett ismeretek előnyként jelennek meg a tanár szakosoknál, az elméleti képzés ebben a formában egyik hallgatói csoportnál sem eredményez szignifikánsan kedvezőbb felkészültségérzetet. A hallgatók csaknem hattizede gondolja úgy, hogy aránytalan terhet ró egy pedagógusra, ha sajátos nevelési igényü gyermekkel kell dolgoznia, ebben sem volt eltérés az óvodapedagógus és a tanár szakos hallgatók között.

Szintén nem igazolódott, hogy a leendő óvodapedagógusok számára nagyobb rugalmassággal, elfogadóbb attitüddel járna, hogy az óvodai nevelés nem tartalmaz kötelezően elsajátítandó ismereteket a gyermekek számára. Az általunk alkalmazott ATDP attitűdskálán a két hallgatói csoportban gyakorlatilag azonos, enyhén negatív attitüdöt mértünk 
a fogyatékossággal élő személyek iránt. Az enyhén pozitív tartomány irányába kizárólag az a néhány hallgató billent, akiknek szűkebb családjában található fogyatékossággal élő személy. Az óvoda és az iskola világának különbözőségei elsősorban abban jelentek meg, hogy milyen sérüléstípust véltek jól integrálhatónak a hallgatók. A tanár szakosok a mozgáskorlátozottakat tartják leginkább alkalmasnak az együttnevelésre, míg az óvodapedagógus hallgatók (azonos mértékben) a tanulásban akadályozott és a beszédsérült gyermekeket.

Eredményeink összességében azt mutatják, hogy a megkérdezett pedagógushallgatók az együttnevelésnek főként az árnyoldalait látják. Ezt erősíti meg az is, hogy saját leendő gyermekét mindössze 42 százalékuk járatná integráltan nevelő csoportba vagy osztályba. Úgy tünik tehát, hogy az inkluzív nevelés egyik lényeges feltételét: a leendő pedagógusok felkészültségét és attitüdjét a jelenlegi képzés során nem sikerül kellően fejleszteni.

\section{IRODALOM}

Alghazo, E. M., Dodeen, H. \& Algaryouti, I. A. (2003) Attitudes of Pre-service Teachers Towards Persons with Disabilities: Predictions for the Succes of Inclusion. College Student Journal, Vol. 37. No. 4. pp. 515-521.

BAloghné B. A. (2013) Soproni óvodapedagógus hallgatók felkészültségének vizsgálata a fogyatékossággal élö gyermekek együttnevelésére. Képzés és gyakorlat, Vol. 11. No. 1-4. pp. 125-132.

CsáNy Y. (1993) Integrált fejlesztés a kutatás szintjén. In: CsáNYi Y. (ed.) Együttnevelés speciális igényü tanulók az iskolában. Az integrált fejlesztés lehetöségei. Budapest, Iskolafejlesztési Alapítvány, OKI Iskolafejlesztési Központ. pp. 22-28.

CsÁNyi Y. (2001) Különtámogatás: szegregáltan vagy integráltan. Educatio, Vol. 10. No. 2. pp. $232-243$.

Fischer G. (2009) Az integrációval kapcsolatos attitűdök kutatása. Gyógypedagógiai Szemle, Vol. 37. No. 4. pp. 254-268.

Foreman, P. J. (2001) Integration and Inclusion in Action. New South Wales, Harcourt Brace and Company.

Horváthné M. I. (2006) Attitűdvizsgálat pedagógusok körében az integrált nevelésről. Iskolakultúra, Vol. 16. No. 10. pp. 81-97.

Loreman, T. (2002) Teacher Education and Inclusion. Paper presented at the XIIIth World Congress of Inclusion International, Melbourne, Australia.

Lynas, W. (1995) Tapasztalatok a siketek integrált oktatásáról az Egyesült Királyságban. In: CsÁNy I Y. (ed.) Együttnevelés - Speciális igényü tanulók az iskolában. Budapest, Iskolafejlesztési Alapítvány OKI Iskolafejlesztési Központ. pp. 55-65.

Némethné T. Á. (2009) Tanári attitűdök és inkluzív nevelés. Magyar Pedagógia, Vol. 109. No. 2. pp. 105-120.

Perlusz A. \& Torda Á. (2010) Pedagógusképzési programok utóélete - Egy hatásértékelő tanulmány tükrében. Felsöoktatási Mühely, Vol. 2. pp. 125-135.

Pongrácz K. (2005) Tanulók fogyatékossággal élő társakkal szembeni attitüdjének vizsgálata. Gyógypedagógiai Szemle, Vol. 43. No. 4. pp. 290-304.

RÉThy E.-NÉ (2002) A speciális szükségletű gyermekek nevelése, oktatása Európában. Az integráció és inklúzió elméleti és gyakorlati kérdései. Magyar Pedagógia, Vol. 102. No. 3. pp. 281-300. 
RÉTI Cs. \& CsÁNYi Y. (1998) Gyakorló pedagógusok és leendő tanítók attitűdjeinek felmérése az integráció témájában. Gyógypedagógiai Szemle, Vol. 26. No. 2. pp. 81-89.

Sharma, U., Forlin, C., Loreman, T. \& Earle, C. (2006) Pre-service Teachers' Attitudes, Concerns and Sentiments about Inclusive Education: An International Comparison of Novice Pre-service Teachers. International Journal of Special Education, Vol. 21. No. 2. pp. 80-93.

Szabó D. (2016) Látlelet a pedagógusok befogadó neveléshez-oktatáshoz való hozzáállásáról. Iskolakultúra, Vol. 26. No. 4. pp. 21-36.

Szegő Á. (2008) Pedagógusok attitűdje az integrált oktatással kapcsolatban. Alkalmazott Pszichológia, Vol. 10. No. 3-4. pp. 21-34.

Yuker, H. E., Block, J. R. \& Younng, J. H. (1970) The Measurement of Attitudes Toward Disabled Persons. New York, Human Resources Center.

A cikk a Creative Commons Attribution 4.0 International License (https://creativecommons.org/licenses/ by/4.0/) feltételei szerint publikált Open Access közlemény, melynek szellemében a cikk bármilyen médiumban szabadon felhasználható, megosztható és újraközölhető, feltéve, hogy az eredeti szerző és a közlés helye, illetve a CC License linkje és az esetlegesen végrehajtott módosítások feltüntetésre kerülnek. (SID_1) 